\title{
Designation and Description of the Type Strain of Lactobacillus casei subsp. alactosus Rogosa et al.
}

\author{
CHARLES K. MILLS and ERWIN F. LESSEL
}

American Type Culture Collection, Rockville, Maryland

\begin{abstract}
In 1953 Rogosa et al. described and named a new subspecies, Lactobacillus casei subsp. alactosus. However, they did not designate the type strain for this subspecies. Therefore strain OC 17 of Rogosa et al. (=ATCC 27216), one of the strains on which the original description was based, is here described and designated as the type strain of $L$. casei subsp. alactosus.
\end{abstract}

Rogosa et al. (8) described a new subspecies of Lactobacillus casei for which they proposed the name $L$. casei subsp. alactosus. The differentiating characteristic between $L$. casei subsp. case $i$ and $L$. case $i$ subsp. alactosus is the inability of the latter to ferment lactose. Although the name $L$. casei subsp. alactosus was validly published, the authors did not designate the type strain of their new subspecies. According to Rule 9a of the International Code of Nomenclature of Bacteria (6), a type shall be designated for each named subspecies. If the original author failed to designate a type strain, a subsequent author may designate the type (Rule 9d[3]). Consequently, strain OC 17 of Rogosa et al., one of the strains upon which the original description of the subspecies was based, was examined for its suitability to serve as the type strain of $L$. casei subsp. alactosus.

Bacterial strain. Strain OC 17 was isolated by Rogosa et al. (8) from the saliva of a child from Boston. According to Rogosa (personal communication) this is one of the strains on which the original description of $L$. casei subsp. alactosus was based, and it is suitable for designation as the type strain. This strain has been deposited in the American Type Culture Collection (ATCC), Rockville, Maryland, under the number 27216.

Media and Methods. Except as noted below, the media and the methods used to characterize strain OC 17 were described by Rogosa et al. (8).

Cells grown on MRS (de Man, Rogosa, and Sharpe) medium (2) were stained using Hucker's modification of the gram stain (7). Growth on MRS medium was also used for detecting the production of catalase (4).
Gelatin liquefaction was determined by the method given in the 1962 edition of Difco Supplementary Literature (3).

The procedures used for determining the action on litmus milk and the reduction of nitrate are described in the Manual of Microbiological Methods (7). The nitrate broth employed had the following composition: casitone, $10.0 \mathrm{~g}$; yeast extract, $3.0 \mathrm{~g}$; $\mathrm{KNO}_{3}, 2.0 \mathrm{~g}$; and distilled water, 1.0 liter.

The benzidine test was performed as described by Deibel and Evans (1).

The lactic acid enantiomorph produced by strain OC 17 was determined with lactic dehydrogenase (Boehringer Mannheim Corp., N.Y.) and nicotinamide adenine dinucleotide (5).

In addition to the carbohydrates tested by Rogosa et al. (8), the following were included here in the characterization of strain OC 17 and were sterilized as follows: D-arabinitol and D(-)ribose were sterilized by filtration and added to the medium aseptically; amygdalin, dextrin, meso-erythritol, $D(+)$ fucose, L-fucose, D-glucoheptose, glycerol, glycogen, $\alpha$-methyl-Dxyloside, perseitol, and D-tagatose were added to the basal medium and sterilized by autoclaving.

The description of $L$. casei subsp. alactosus strain OC 17 is as follows. Gram-positive rods, 0.6 by $1.4 \mu \mathrm{m}$, occurring singly but more frequently in short chains. Nonmotile. Endospores not produced.

Surface colonies on MRS medium were smooth, glistening, and white and measured 1 to $2 \mathrm{~mm}$ in diameter. No pigment was produced. Catalase was not produced. The benzidine test was negative. Nitrate was not reduced. Gelatin was not liquefied. There was 
no change in either skim or litmus milk. Ammonia was not produced from arginine. Esculin and hippurate were hydrolyzed, but starch was not.

Riboflavine, folic acid, calcium pantothenate, and niacin were required for growth whereas thiamine, vitamin $B_{12}$, and thymidine were not.

This organism is homofermentative, lactic acid [L(t) lactic acid] being the primary product from glucose. In the original description by Rogosa et al. (8), this organism was described as producing dextro-rotatory lactic acid (D-lactic acid), i.e., L(+)lactic acid according to the present convention.

Gluconate is fermented with the production of acid and gas $\left(\mathrm{CO}_{2}\right)$.

Amygdalin, $\mathrm{D}(+)$ cellobiose, dulcitol, $\mathrm{D}(+)$ galactose, $\mathrm{D}(+)$ glucose, inulin, $\mathrm{D}(+)$ maltose, D-mannitol, $\mathrm{D}(+)$ mannose, $\mathrm{D}(+)$ melezitose, $\alpha$-methyl-D-glucoside, $\quad \mathrm{D}(-)$ ribose, salicin, D-sorbitol, sucrose, D-tagatose, $\mathrm{D}(+)$ trehalose, and $\mathrm{D}(+)$ turanose were fermented with the production of acid but not gas. D-arabinitol, dextrin, meso-erythritol, $D(+)$ fucose, L-fucose, D-glucoheptose, glycerol, glycogen, D-lactose, $\mathrm{D}(+)$ melibiose, $\quad \alpha$-methyl-D-mannoside, $\quad \alpha$ methyl-D-xyloside, perseitol, D-raffinose, Lrhamnose, ribitol, L(-)sorbose, starch, xylitol, and D-xylose were not fermented.

The cell wall contained muramic acid, and the tetrapeptide bound to the muramic acid contained L-alanine, D-glutamic acid, L-lysine, and D-alanine; the cross-linking amino acid bound to the $\epsilon$-amino group of L-lysine was D-aspartic acid (O. Kandler, personal communication).

The guanine plus cytosine (GC) content of the deoxyribonucleic acid was found to be 46.6 mol \% (buoyant density) (M. Mandel, personal communication).

With but a few minor exceptions, the characters of strain OC 17 agree with those recorded in the original description of $L$. case $i$ subsp. alactosus: strain OC 17 fermented inulin and did not ferment sorbose whereas the opposite results are given in the original description of the subspecies. However, these differences do not affect the basic concept of L. casei subsp. alactosus, and from a taxonomic standpoint can be disregarded. For all practical purposes, then, the characters of strain OC 17 agree with those recorded in the original description of $L$. casei subsp. alactosus, and this strain is here designated as the type strain of this subspecies.

The authors thank $O$. Kandler and Manley Mandel for determining the cell-wall composition and the GC content of the deoxyribonucleic acid, respectively, of strain OC 17.

Address requests for reprints to: Mr. Charles Mills, American Type Culture Collection, 12301 Parklawn Drive, Rockville, Md. 20852.

\section{LITERATURE CITED}

1. Deibel, R. H., and J. B. Evans. 1959. Modified benzidine test for the detection of cytochromecontaining respiratory systems in microorganisms. J. Bacteriol. 79:356-360.

2. de Man, J. C., M. Rogosa, and M. E. Sharpe. 1960. A medium for the cultivation of lactobacilli. J. Appl. Bacteriol. 23:130-135.

3. Difco Supplementary Litera ture. 1962. Difco Laboratories, Detroit, Michigan.

4. Hansen, P. A. 1968. Type strains of Lactobacillus species. American Type Culture Collection, Rockville, Maryland.

5. Hohorst, H.-J. 1963. In H.-U. Bergmeyer (ed.), Methods of enzymatic analysis. Academic Press Inc., New York.

6. International Code of Nomenclature of Bacteria. 1966. Int. J. Syst. Bacteriol. 16:459-490.

7. Pelczar, M. J., Jr., et al. 1957. Manual of microbiological methods. McGraw-Hill Book Co., Inc., New York.

8. Rogosa, M., R. F. Wiseman, J. A. Mitchell, M. N. Disraely, and A. J. Beaman. 1953. Species differentiation of oral lactobacilli from man including descriptions of Lactobacillus salivarius nov. spec. and Lactobacillus cellobiosus nov. sp. J. Bacteriol. 65:681-699. 